\title{
LIFE AND WORK OF ACADEMICIAN MOMIR POLENAKOVIC
}

OFFICIAL ADDRESS OF ACADEMICIAN V. KAMBOVSKI, PRESIDENT OF THE MACEDONIAN ACADEMY OF SCIENCES AND ARTS ON THE OCCASION OF THE $75^{\mathrm{TH}}$ ANNIVERSARY OF ACADEMICIAN MOMIR POLENAKOVIC

\section{Vlado Kambovski}

Macedonian Academy of Sciences and Arts, Skopje, R. Macedonia

Corresponding author: V. Kambovski, Macedonian Academy of Sciences and Arts, Bul. Krste Misirkov, No. 2, Skopje, Republic of Macedonia

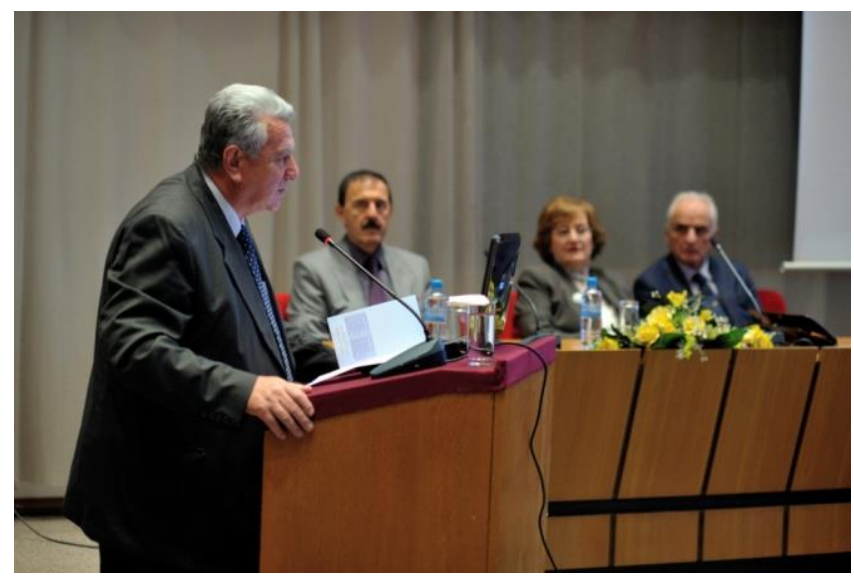

From left to right: V. Kambovski (Skopje), Z. Popov (Skopje), N. Pop-Jordanova (Skopje), I. Filipce (Skopje)

\begin{abstract}
Talking about Acad. Momir Polenakovic, on the occasion of his $75^{\text {th }}$ anniversary and 50 years of work, it is my pleasure to say that he is one of the rare medical workers, researchers, visionaries and educators, especially in the field of nephrology. With his work he became famous in Macedonia and in the world and raised the Macedonian nephrology to a European level. He is characterized with the highest virtues of the scientist: knowledge, diligence, searching for truth and empathy. Acad. Polenakovic is an example to all younger counterparts for his exceptionally correct and friendly relations with all his associates, and, he also supports his younger colleagues in their work and development.
\end{abstract}

Key words: anniversary, medicine, Macedonian nephrology, science, research

Dear Acad. Polenakovic, distinguished Academicians, Ladies and Gentlemen, representatives of the Serbian Academy of Sciences and Arts and of the Bulgarian Academy of Sciences, distinguished Professors, Deans, colleagues, respected Ambassador of the Republic of Croatia to the Republic of Macedonia.
I am honored at the beginning of the International Nephrology Days to talk about the life and work of Acad. Momir Polenakovic, our distinguished member, known not only in the scientific circles of the Macedonian society, but also in the Balkans and in Europe with his works, and particularly known for his friendly relations with the colleagues around the world. 
We at the Academy are honored that Acad. Polenakovic has been its member for many years now and that he gives a major contribution to the development of the Academy and in the exercise of its activities. Particularly, today it is a great honor for me to speak on the occasion of his $75^{\text {th }}$ birthday, which is also a reason for organizing this important conference attended by scientists from many countries of our region and Europe. On behalf of the Academy I would like to thank them for being present today and tomorrow, and they will take an active part in this important event, which is accredited by the European Accreditation Council for Continuing Medical Education and thus, it gets a true meaning of a serious scientific event.

Allow me at the beginning to present the life and work of Acad. Polenakovic. Academician Polenakovic was born on 26.04.1939 in Skopje in a family of intellectuals. His father was a Professor at the University of Ss. Cyril and Methodius in Skopje, and also one of the founders of the Macedonian Academy of Sciences and Arts and its first Vice President. Momir Polenakovic's mother was a graduate in ethnology at the Faculty of Philosophy in Skopje between the two world wars and she was one of the founders of the first Ethnographical Museum in Skopje and Macedonia after the Second World War. He grew up in a family where the atmosphere of research was present every day. The family supported Momir Polenakovic as a scholar and student to participate in different activities related to research. He was the best student of the generation at the Medical Faculty of the Ss. Cyril and Methodius University in Skopje in 1963.

He married Biljana Polenakovic Filipce, a specialist in medical biochemistry and longlasting Director of the Institute of Clinical Biochemistry at the Medical Faculty in Skopje. They have two sons, Hari and Radmil. She was not only a good mother and wife, but also a researcher who helped him in the field of biochemistry and who helped him in his research of nephrology.

Acad. Polenakovic is a retired Professor in internal medicine at the Medical Faculty in Skopje. He is an Honorary President of the
Macedonian Society of Nephrology, Dialysis, Transplantation and Artificial Organs; member of the Macedonian Academy of Sciences and Arts - Vice President of the Academy from 2004 to 2007 and Secretary of the Department of Biological and Medical Sciences of the Academy from 2002 to 2004. Now, he is a Head of the Research Center for Genetic Engineering and Biotechnology of the Academy. In the period from 1981 to 1984 he was a Vice Dean of the Medical Faculty in Skopje; in the period 1990 to 1997 he was a Head of the Nephrology Clinic at the Ss. Cyril and Methodius University in Skopje. In the period from 1984 to 1986 he was a President of the Macedonian Medical Association. He was a President of the Association of Nephrologists of Yugoslavia; President of the Macedonian Society of Nephrology, Dialysis, Transplantation and Artificial Organs; President of the MacedonianAmerican Friendship Association "Macedonia"; Founder and President of the Balkan Cities Association of Nephrology, Dialysis, Transplantation and Artificial Organs (BANTAO). 


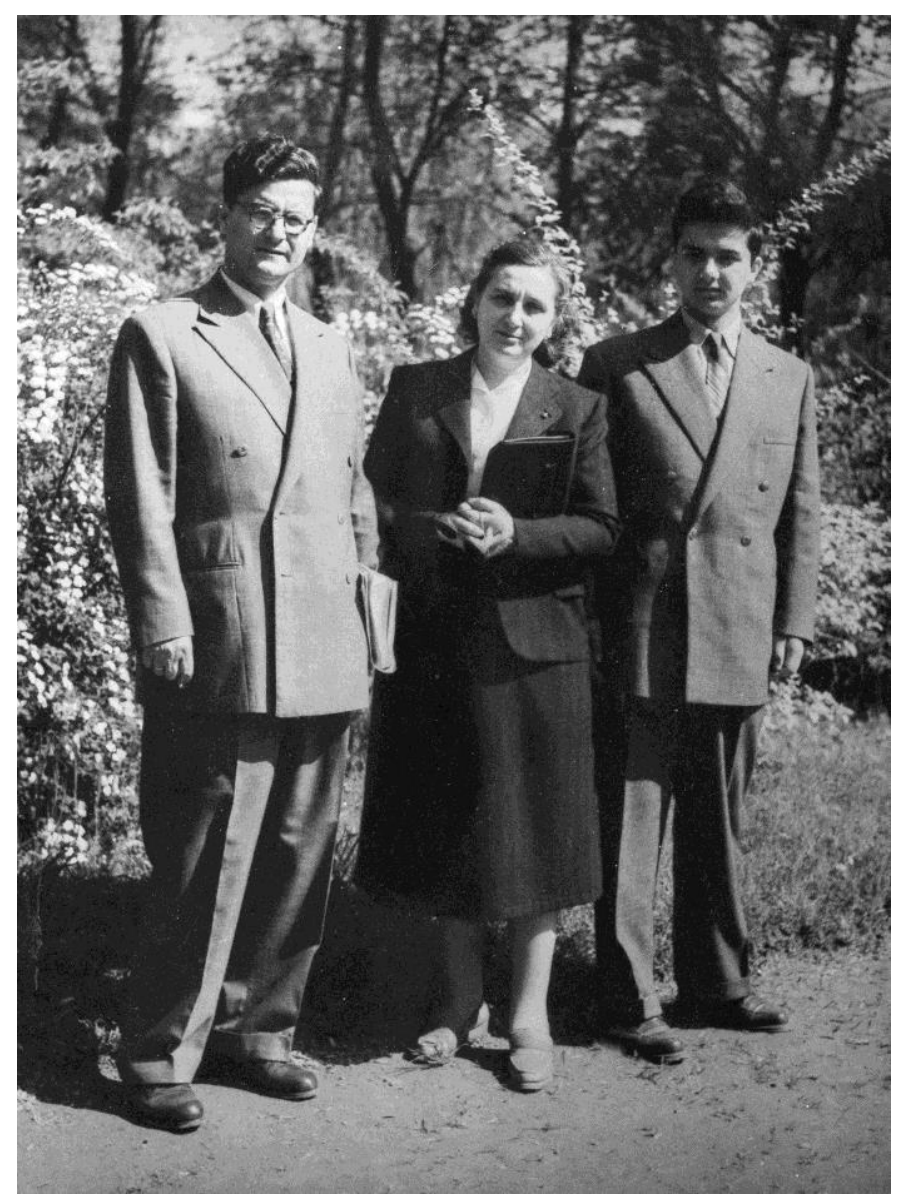

Fig. 1-M. Polenakovic as a boy with his father Haralampie and his mother Radmila

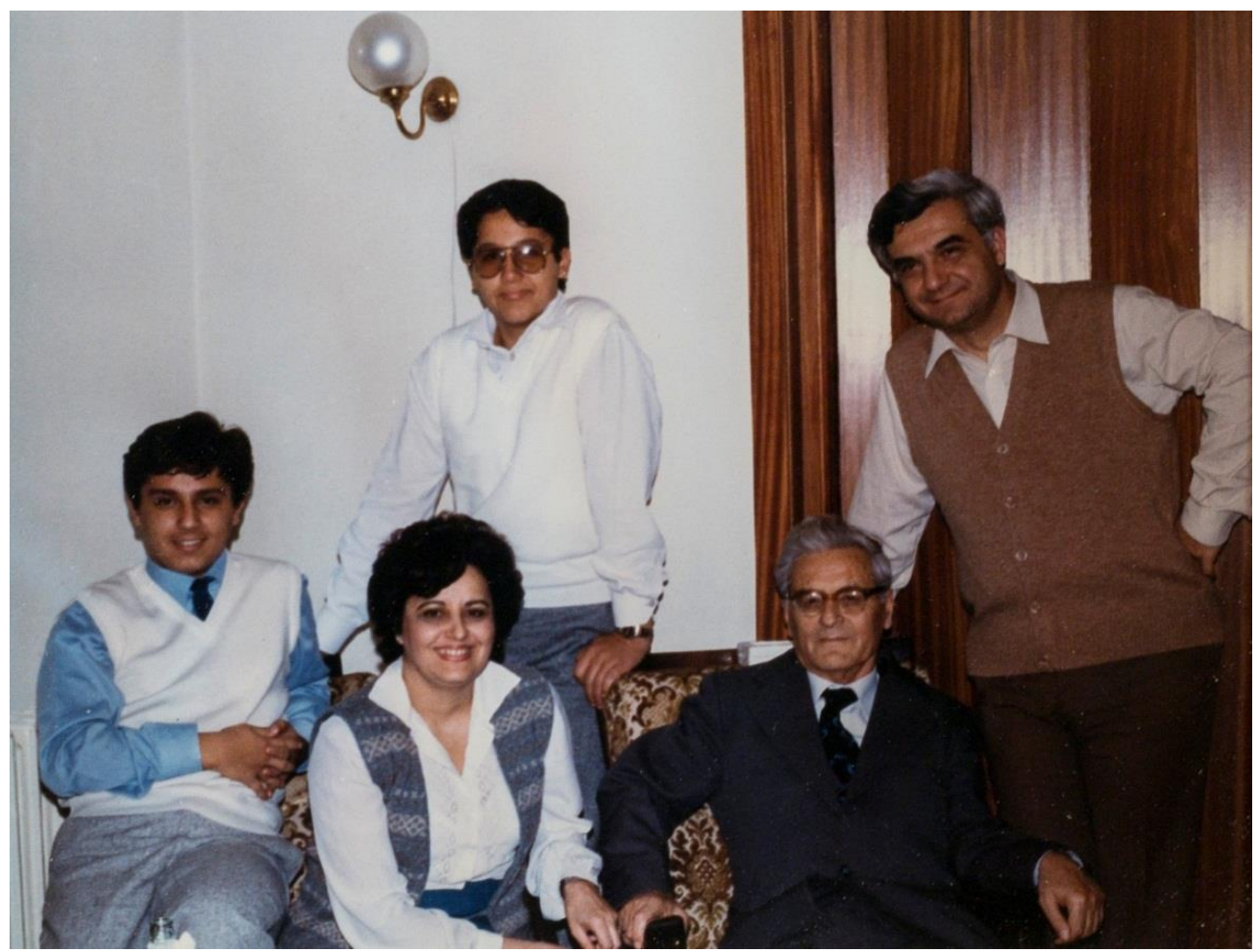

Fig. 2 - M. Polenakovic with his wife Biljana, the two sons Radmil and Hari and Polenakovic's father, Academician Haralmpie Polenakovic 
M. Polenakovic has been awarded the highest national and international awards and acknowledgments for his long lasting work. He has received the highest award of the Macedonian Medical
Association - the Trifun Panovski Diploma, as well as the highest national award 11 October for scientific work and the 13 November Award of the city of Skopje.

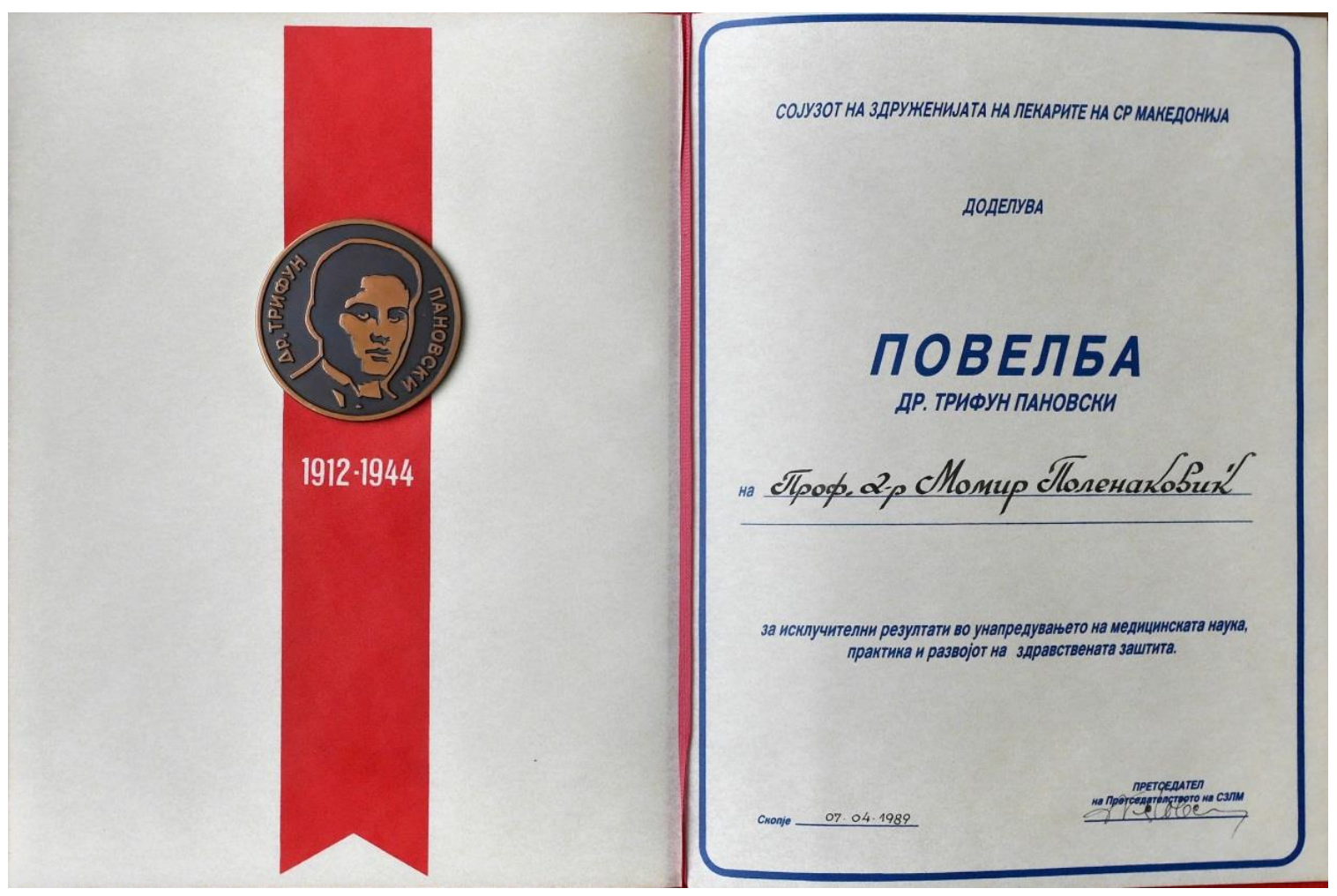

Fig. 3 - Trifun Panovski Diploma

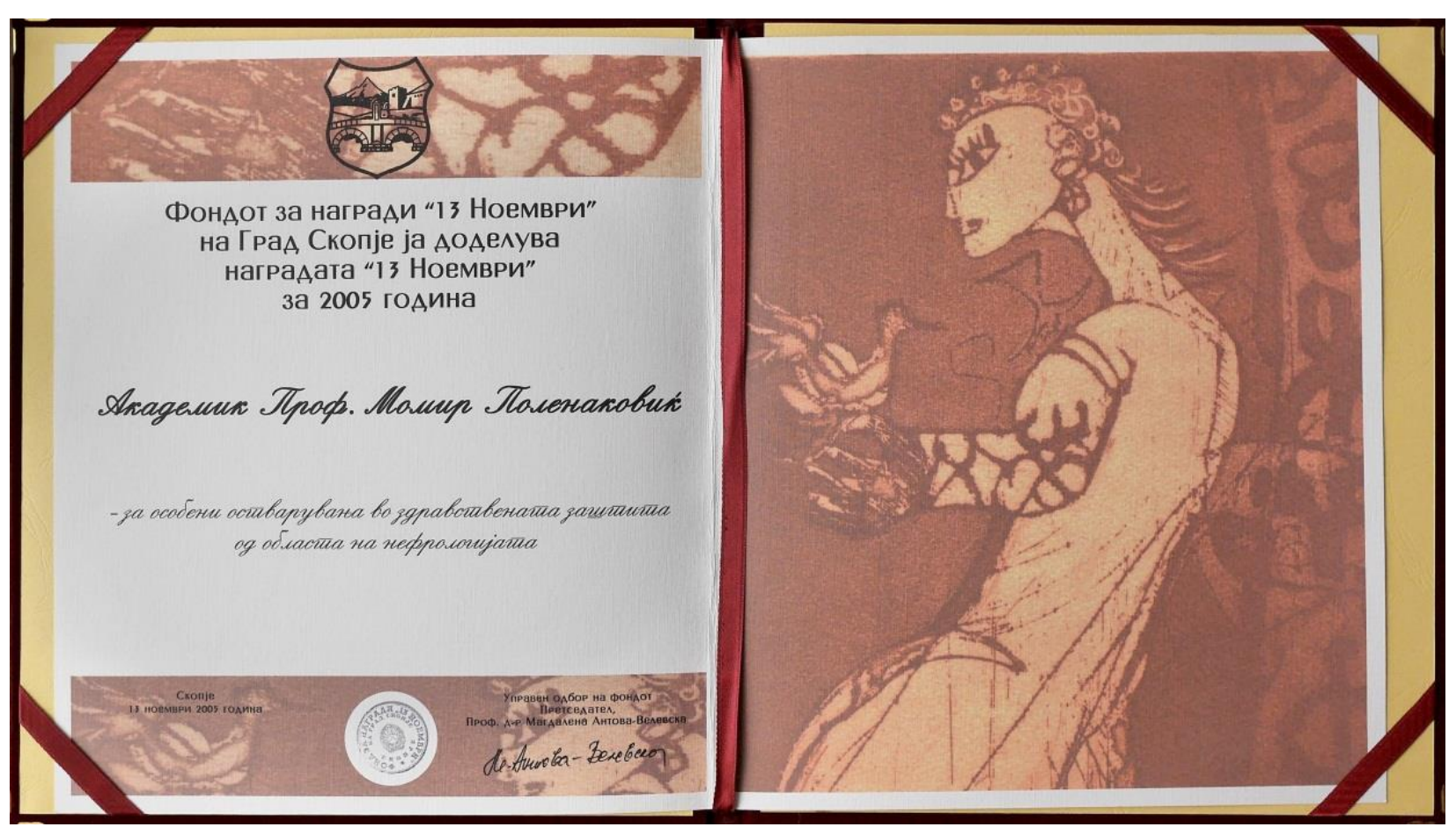

Fig. 4-13 November Award 

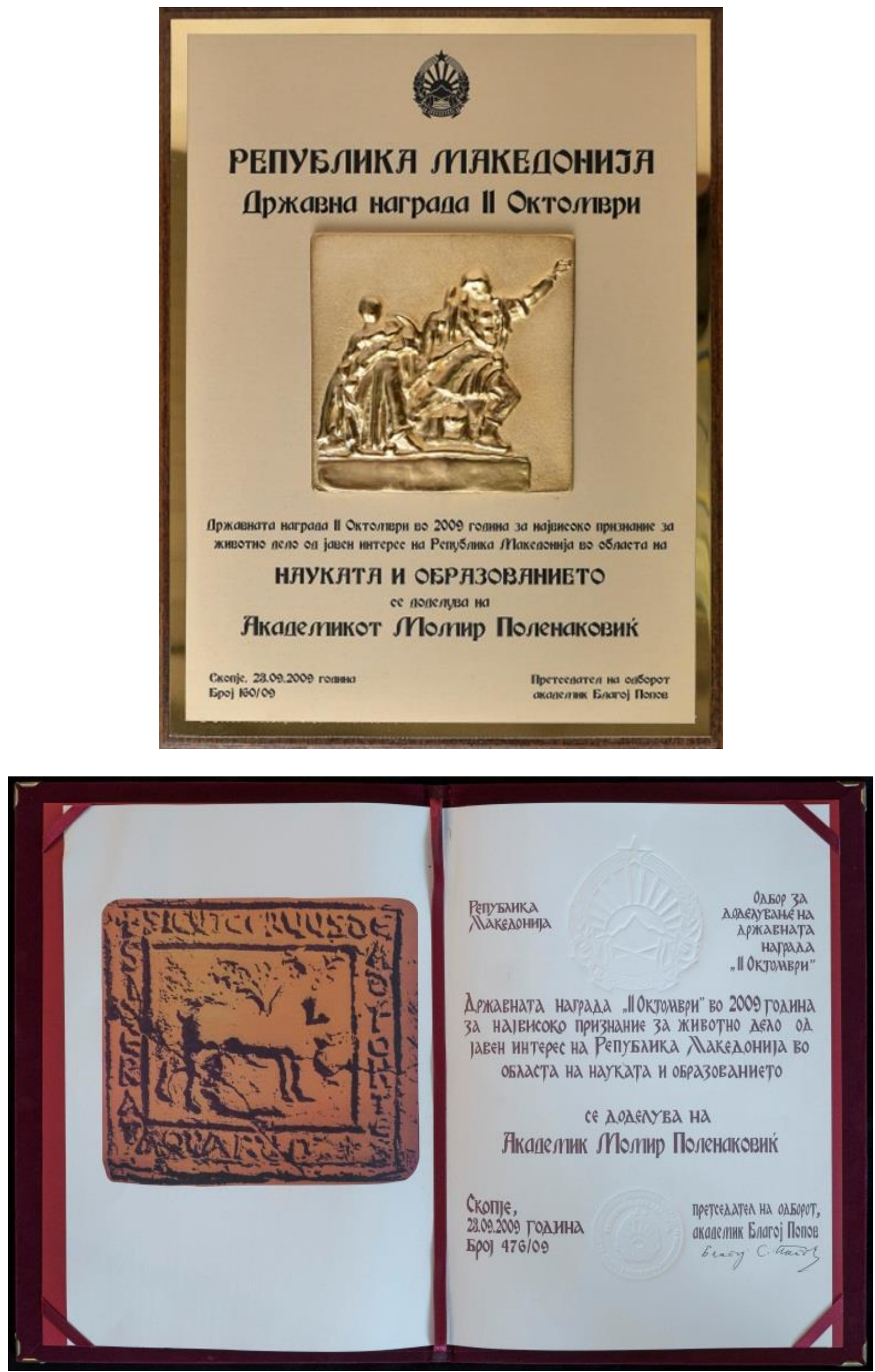

Fig. 5 - The highest national award 11 October 
For all his activities, quite extensive and very responsible tasks, he was awarded the International medal in 1997 of the National Kidney Foundation of the United States of America, the highest honor awarded by the Foundation to nephrologists outside the United
States of America for outstanding scientific achievements in nephrology and prominent public work in their community. He has also received the award of the International Society of Nephrology for a Pioneer in nephrology in the Eastern and Central European region.

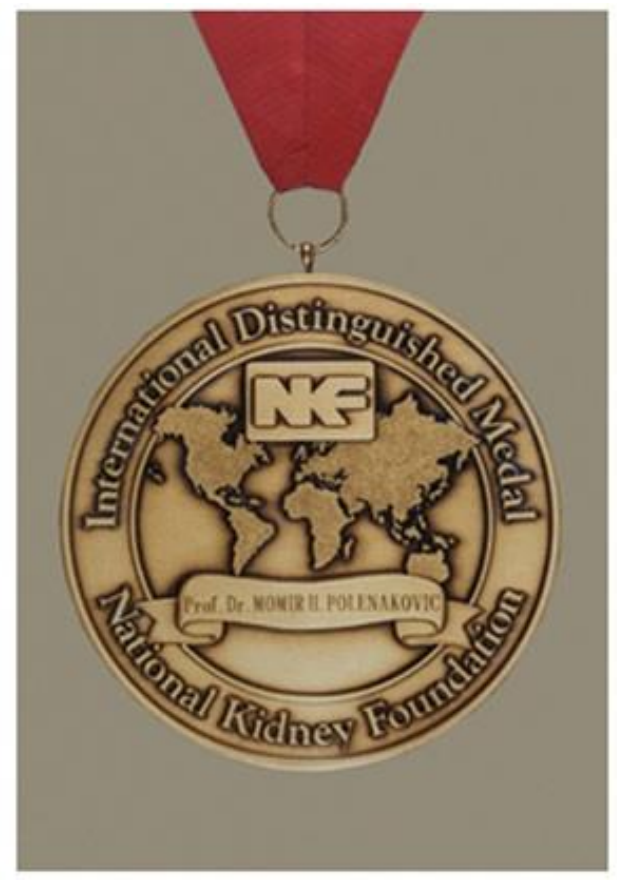

Fig. 6 - International medal in 1997 of the National Kidney Foundation of the United States of America

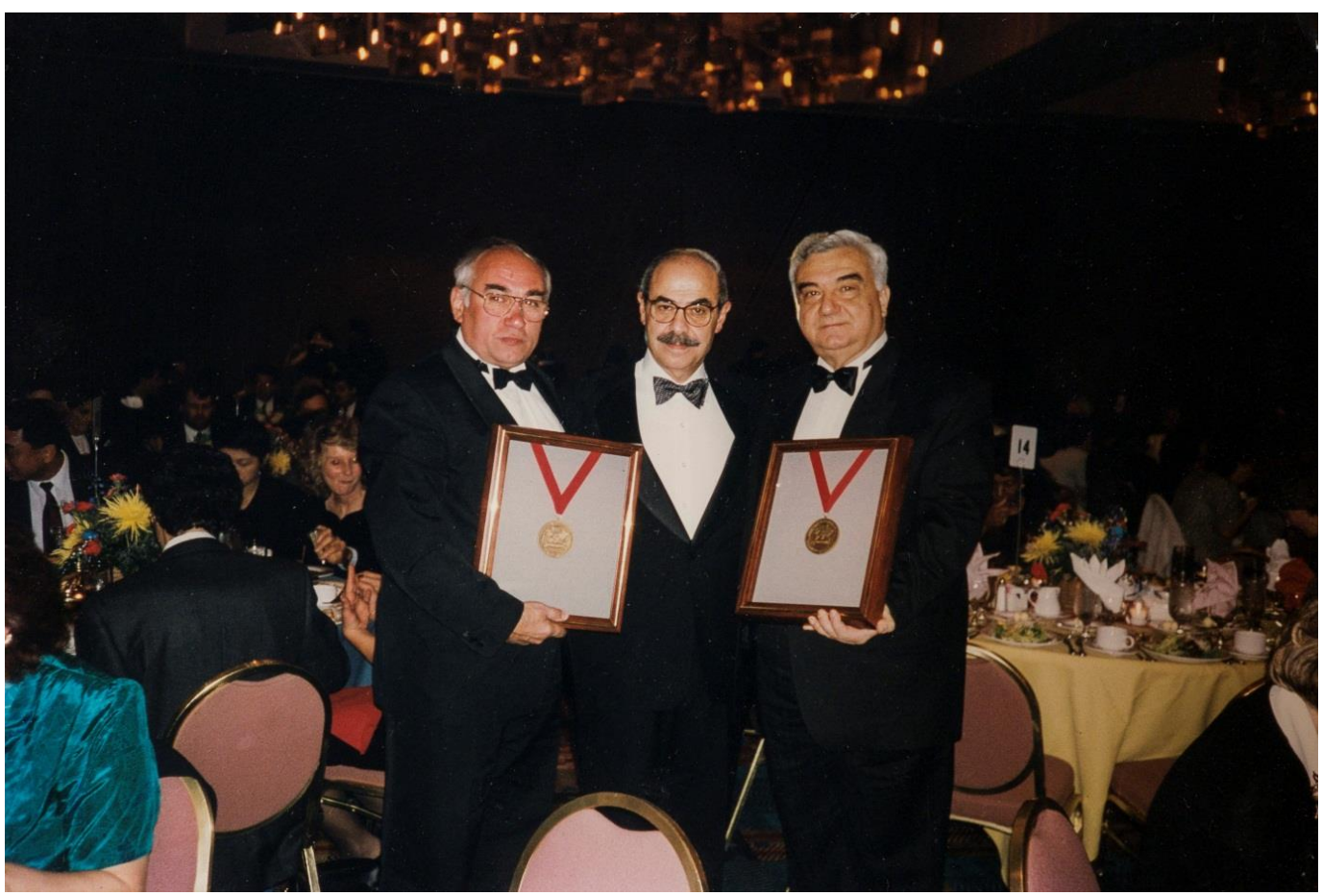

Fig. 7 - Recipients of the International medal in 1997 of the National Kidney Foundation of the United States of America, from left to right: B. Rutkowski (Poland), G. Eknoyan, President of the National Kidney Foundation of the USA and M. Polenakovic (Republic of Macedonia) 
As recognition of the scientific work of Acad. M. Polenakovic, he has been elected a member of several national academies of sciences and arts: Macedonian Academy of Sciences and Arts, Serbian Academy of Sciences
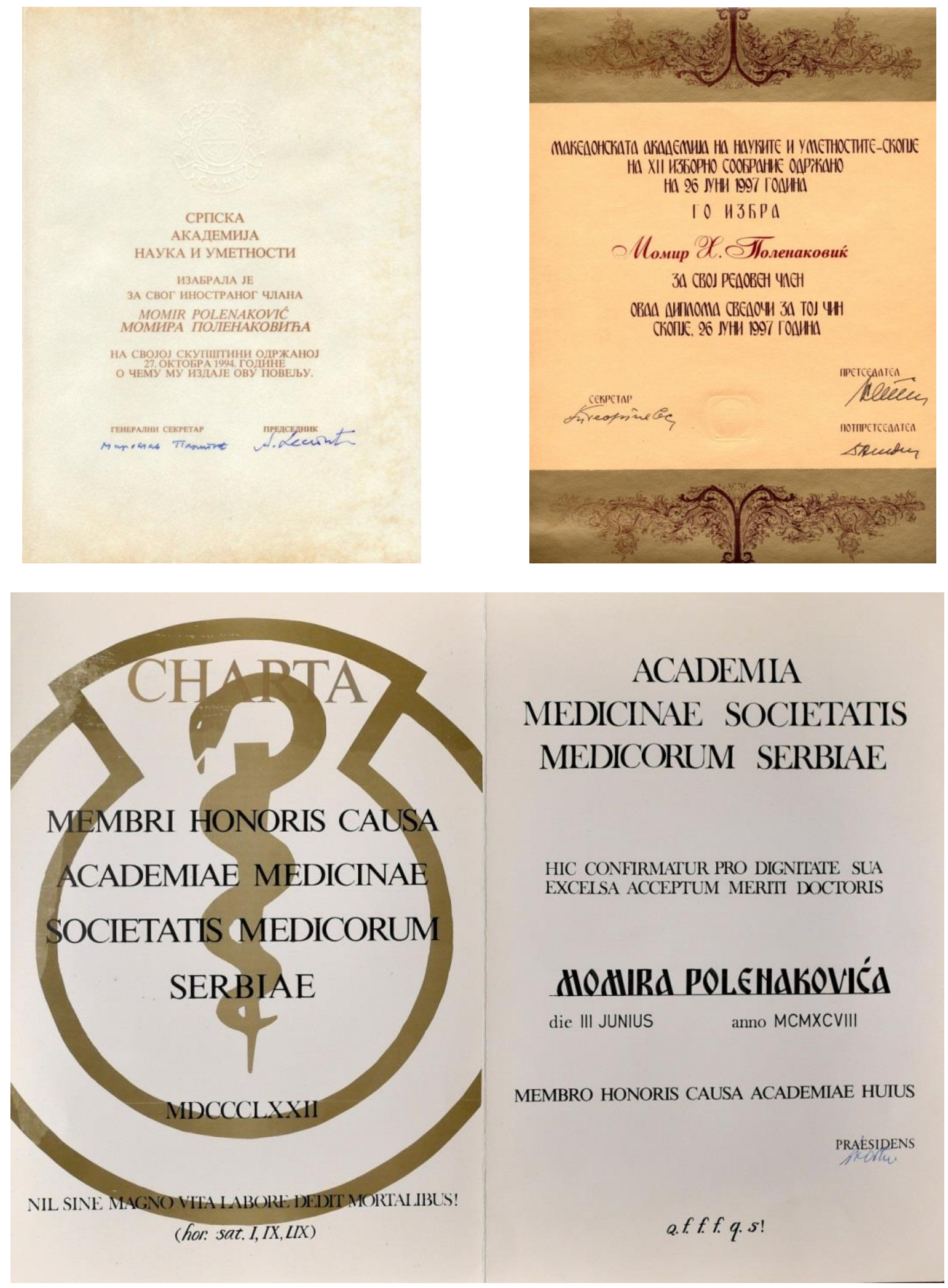

and Arts, Croatian Medical Academy, Serbian Medical Academy, European Academy of Sciences and Arts, World Academy of Art and Science and the Leibniz Society of Sciences from Berlin.

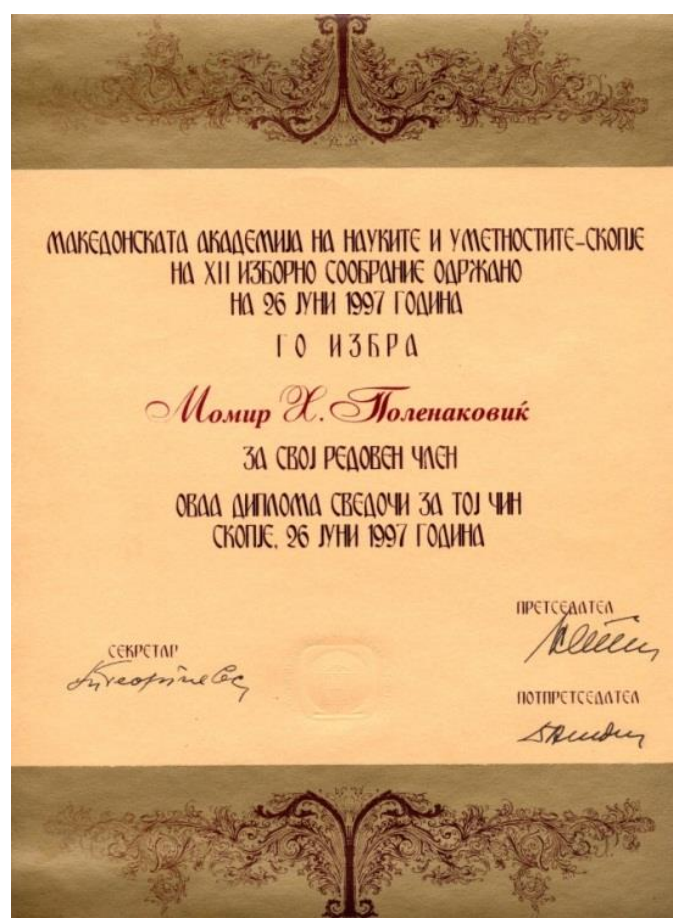

\section{MEDICINAE SOCIETATIS MEDICORUM SERBIAE}

HIC CONFIRMATUR PRO DIGNITATE SUA EXCELSA ACCEPTUM MERITI DOCTORIS

\section{HOHIRA POLEHAKOVIĆA}

die III JUNIUS 

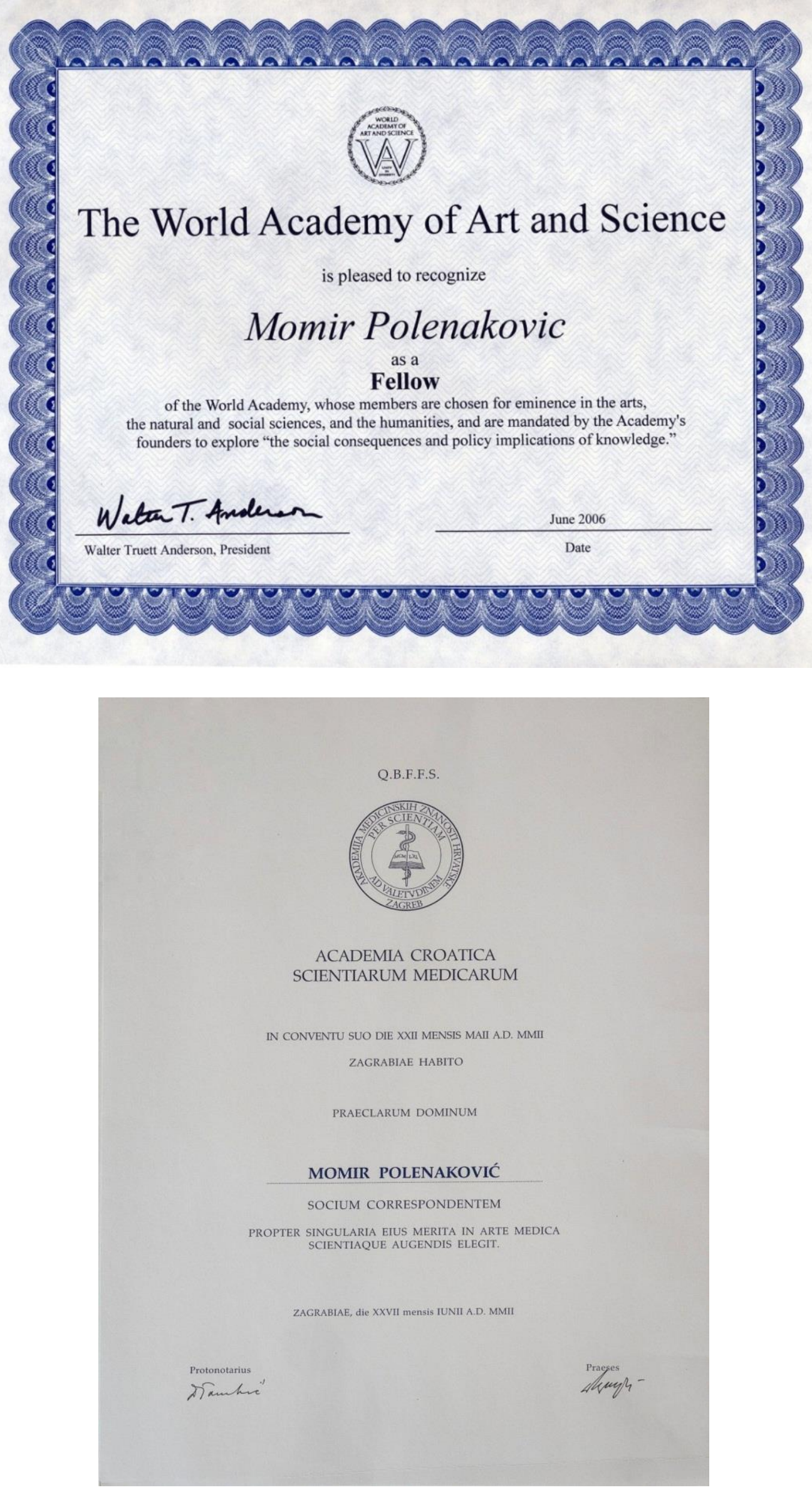
Q.F.F.F.Q.S.

IN ACADEMIA SCIENTIARUM ET ARTIUM EUROPAEA NOS

FELIX UNGER

FELIX UNGER
ACADEMIAE CONDITOR ET H.T. PRAESES

NICOLAUS LOBKOWICZ

ACADEMIAE CONDITOR ET H.T. PROPRAESES PRIOR FRANCISCUS IOSEPHUS RUBIA ERICH HOODL
H.T. PROPRAESIDES

MANDATA SENATUS DILIGENTER EXSEQUENTES

MAGNO CUM GAUDIO

IN DOMINUM CLARISSIMUM

\section{$\underset{\text { SCOPIENSEM }}{\text { MOMIR POLENAKOV́́ }}$}

OB EXIMIA EIUS MERITA ELECTUM SOCII ORDINARII

IN CLASSE SCIENTIARUM MEDICARUM

NOMEN ET HONORES IURA ET PRIVILEGIA CONTULIMUS
IN EIUSOUE REI FIDEM HASCE LITTERAS IN EIUSQUE REI FIDEM HASCE LITTERAS
ACADEMIAE SIGILLO SANCIENDAS CURAVIMUS.

Hoc diploma excerptum cum Academiae matricula sub numero 166747 ad verbum concordare fidem facimus.

SALISBURGI, die III. mensis Martii anni p.Chr.n. MMVII.
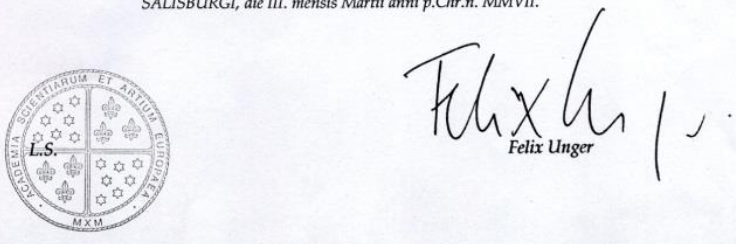

During the International Nephorlogy Days meeting in 2014, Acad. M. Polenakovic was awarded the order of the Bulgarian Aca- demy of Sciences. The order was presented by Acad. A. Galabov from the Bulgarian Academy of Sciences.

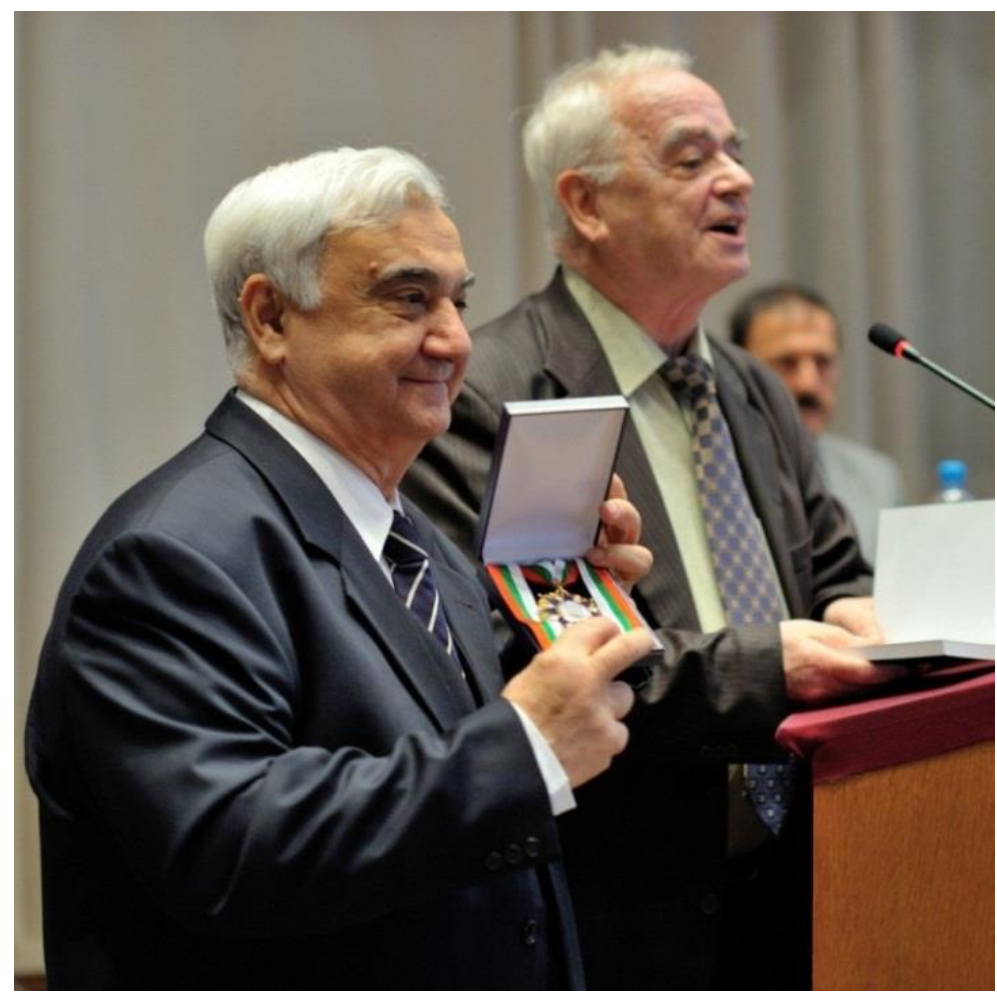




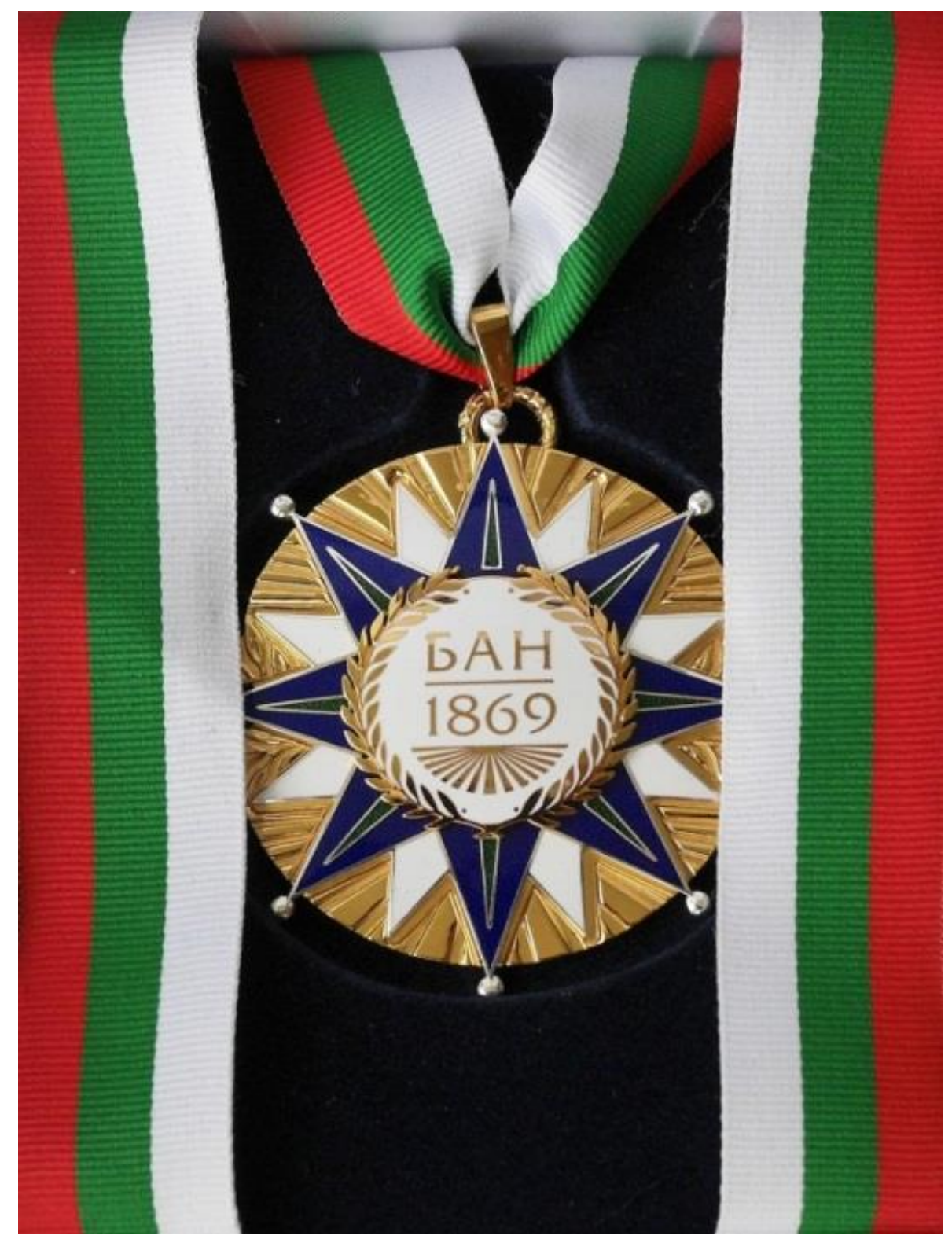




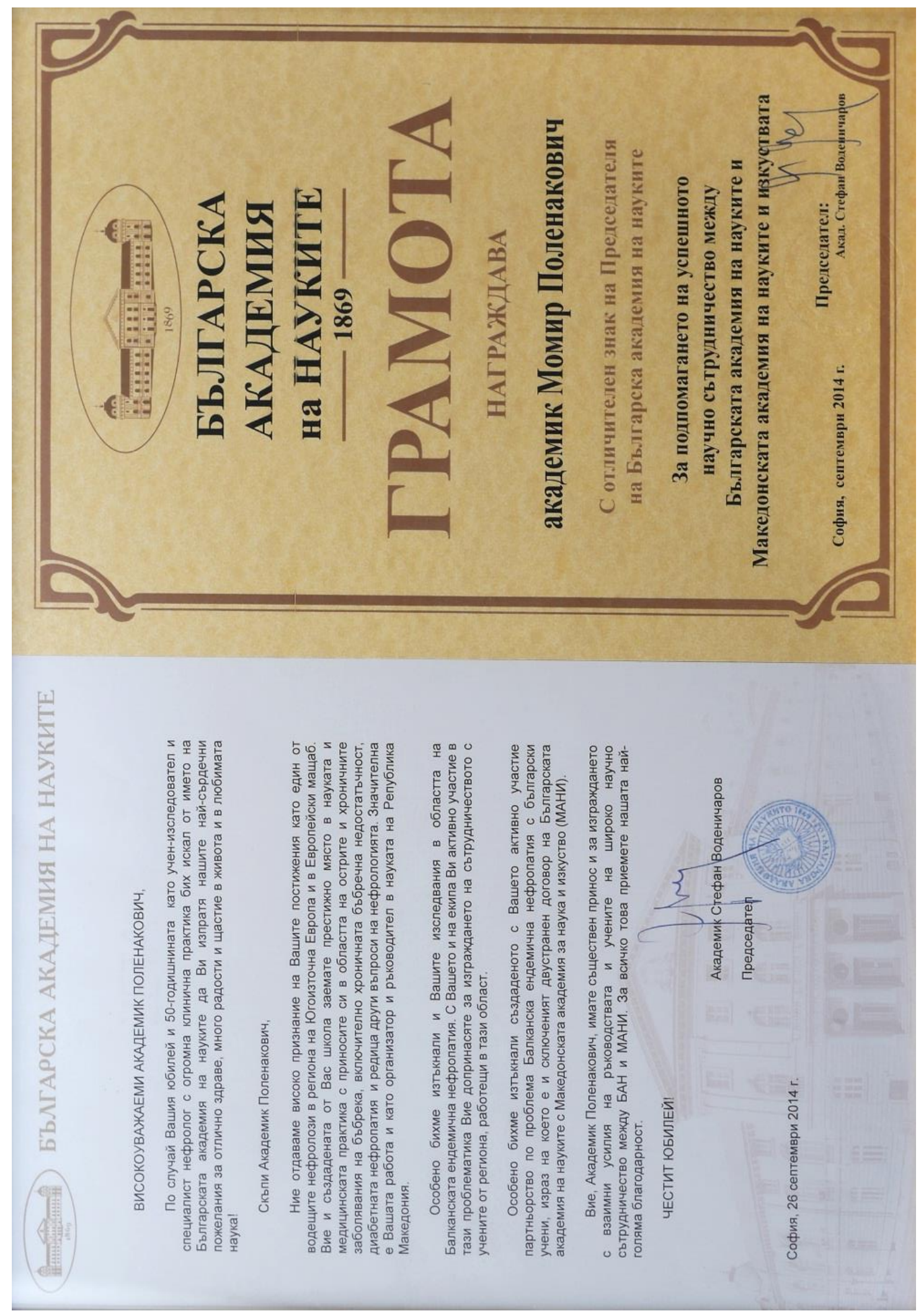

M. Polenakovic was also awarded with the GRAMOTA by the Bulgarian Academy of Sciences

These awards of Academician Polenakovic testify to his enormous merits and contribution to the development of the medical science, not only in the field of nephrology, but also in wider areas. Academician Polenakovic's generous contribution to the development of science continues today. He is extremely active in the area of scientific research. He is 
an Editor in Chief of the journal "PRILOZI", journal of the Department of Medical Sciences of the Macedonian Academy of Sciences and Arts. Since 2002 he has been an Assistant Editor of the respectable journal "BANTAO", member of the editorial board of the "Macedonian Medical Review" and others. He is a former member of the editorial board of the journal "Nephrology, Dialysis, Transplantation" of the ERA-EDTA; of the journal "JAMA", the American Medical Association, Yugoslav edition. Acad. Polenakovic today presents us with a very large number of published papers which are collected in the works that are presented here. In his extremely productive life he has published around 500 papers, of which many are original papers and 189 papers are on the PubMed; also, 363 abstracts, several books and book chapters, then he has led research projects with partners from abroad -7 and national research projects - 14. And, as I mentioned today, he successfully manages the work of the Research Center for Genetic Engineering and Biotechnology in the Macedonian Academy of Sciences and Arts, a Balkan reference center, that has a very significant domestic and international projects and which include many prominent scientists not only from the Republic of Macedonia but also from abroad, for which on behalf of the Academy I would like to thank him, because the Center places the reputation of the Academy on a very high scientific level.

I could extensively speak about Acad. Polenakovic, and I will quote one of our doyens, Acad. Pop-Jordanov, who said about Acad. Polenakovic that he is characterized with the highest virtues of the scientist: knowledge, diligence, searching for truth and empathy. Concerning the empathy, which is sometimes a difficult characteristics in this difficult times, Acad. Polenakovic is an example to all younger counterparts for his exceptionally correct and friendly relations with all his associates, with all the members of the Academy, with all former associates of the Faculty of Medicine. So, I could talk about him and his diligence very long: for example, Acad. Polenakovic regularly informs his colleagues about all the meetings he attends and about the work on the scientific meetings, the results, the participants and so on. All this talks about his wish to share his knowledge and information with his friends and colleagues.

I congratulate him his $75^{\text {th }}$ birthday, I wish him us to celebrate the future 10 anniversaries, since the Academy celebrates the 10 anniversaries, which means that the time to mark the $80^{\text {th }}$ birthday will quickly come, when he will surely organize us similar spiritual pleasures, and also, to organize an international conference and to present new papers. On behalf of this, I wish him a good health and further success and happiness and also to his family.

Thank you.

Резиме

\section{ЖИВОТОТ И ДЕЛОТО НА АКАДЕМИК МОМИР ПОЛЕНАКОВИК์}

ОФИЦИЈАЛНО ОБРАК์АЮЕ НА АКАДЕМИК

ВЛАДО КАМБОВСКИ, ПРЕТСЕДАТЕЛ

НА МАКЕДОНСКАТА АКАДЕМИЈА

НА НАУКИТЕ И УМЕТНОСТИТЕ, ПО ПОВОД

75-ГОДИШНИНАТА ОД РАЃАЊЕТО

НА АКАДЕМИК МОМИР ПОЛЕНАКОВИК์

\section{Владо Камбовски}

Македонска академија на науките

и уметностите, Скопје, Р. Македонија

Зборувајќи за акад. Момир Поленаковиќ, по повод одбележувањето на неговиот 75 . роденден и 50 години работа, задоволство ми е да кажам дека тој е еден од ретките медицински работници, истражувачи, визионери и едукатори, особено во областа на нефрологијата. Со својата работа стана познат во Македонија и во светот и ја издигна македонската нефрологија на европско ниво. Тој се карактеризира со најголеми доблести за еден научник: знаење, посветеност, потрага по вистината и емпатија. Акад. Поленаковиќ е пример за сите помлади колеги со своите исклучително коректни и пријателски односи со сите соработници и тој ги поддржува своите помлади колеги во нивната работа и развој.

Клучни зборови: годишнина, медицина, македонска нефрологија, наука, истражување. 